Saeculum Christianum vol. XXII (2015)

pp. $218-224$

\author{
MICHAL KOWALCZYK* \\ WNHiS UKSW, Warszawa
}

\title{
HUNGARY IN JOURNALISM OF ROMAN DMOWSKI (BASED ON POLISH POLITICS AND THE REBUILDING OF THE STATE)
}

\section{Introduction}

History is ripe with the events which forged Polish-Hungarian relations into a form of particular friendship between the nations. Among these events the Polish and Hungarian revolutionaries fighting together during the so called Revolution of 1848 (1848-1849) and the battle against Soviets fought by Hungarian nation in 1956 are commonly listed. At that time the world forgot about Magyars locked in battle but Poles remembered - and supported Hungarian insurrectionist providing blood, medicine and food ${ }^{1}$. The aid provided for Poland by Hungarians in 1920 during the Polish-Bolshevik war ${ }^{2}$ as well as the shelter provided for thousands of Polish refugees by Admiral Horthy during the fall of $1939^{3}$ are also frequently noted.

However, the Polish-Hungarian relations in the interwar period were characterized by passivity. Despite the centuries-old tradition of friendship Warsaw and Budapest did not enter into any form of political or military alliance. It was the result of a completely different position of Poland and Hungary in Central Europe. Poland, as a beneficiary of the so-called Versailles order, was primarily interested in defending its holdings whereas Magyars were pushing for the revision of the Treaty of Trianon (June 4th, 1920) which had tragic consequences for Hungary ${ }^{4}$. Hungarians feared war and in particular the risk of the liberation of Slavs residing in the Hungarian part of Habsburgs Monarchy. Ultimately Budapest agreed to participate in conflict primarily hoping to tame Serbia. It was so due to the fact that Belgrade supported liberation of southern Slavs who in significant numbers resided in Habsburgs Monarchy, particularly in its Hungarian part.

Hungarians considered the Treaty of Trianon a dictate. The delegacy consisting of Albert Apponyi, István Bethlen and Pál Teleki was forced to sign the treaty at the Trianon castle in Versailles. It was a dark day for Hungary, national flags were flown half-mast, public

\footnotetext{
* Translated by Spektra Sp. z o.o.

J. Kochanowski, Wegry. Od ugody do ugody 1867-1990, Warszawa 1997, pp. 161-163.

See; T. Gerencser, Wegry i wojna polsko-bolszewicka, „W Sieci. Historia”, 2014/13 (6), pp. 31-33.

I. Lagzi, Droga żotnierza polskiego przez węgierska granicę w latach 1939-1941, Poznań 1987.

4 J. Kochanowski, op. cit., pp. 67-68.
} 
institutions were closed and bells rung across the country5. Since the fall of 1920 Hungarian pupils were obliged to say national prayer in schools in which the following words were uttered: I believe in the glorious restoration of former Hungary ${ }^{6}$. Trauma of Trianon defined Hungarian national consciousness for the coming decades ${ }^{7}$. Under the provisions of the Treaty of Trianon Hungarians lost more than $70 \%$ of their existing territory and were reduced to approx. $93000 \mathrm{~km}^{2}$. The lost lands were granted to: Romania $-102787 \mathrm{~km}^{2}$, Czechoslovakia $62937 \mathrm{~km}^{2}$ and Kingdom of Serbs, Croats and Slovenes $-63088 \mathrm{~km}^{2}$. Small parts of the territory were also granted to Austria, Poland and Italy. An enormous throng of Magyars found themselves outside of the Hungarian country: approx. 1.7 M in Romany, approx. 1M in Czechoslovakia and more than half a million in Kingdom of Serbs, Croats and Slovenes (soon renamed to Kingdom of Yugoslavia) ${ }^{8}$. The three main beneficiaries of the Treaty of Trianon formed, under the protectorate of Paris, Little Entente which practically isolated Hungary on the international forum and protected territorial acquisitions of Belgrade, Bucharest and Prague.

While the Hungarian delegacy was leaving Versailles in sombre moods Roman Dmowski (1864-1939) $)^{9}$, the leader of National Camp, president of the Polish National Committee and signatory of the Treaty of Versailles, could have been satisfied with the results. In this context his 1925 „Polish Politics and the Rebuilding of the State" be particularly interesting. In this work he clearly presented his views, particularly those concerning the position of Poland in Europe, and the motives behind his policy - both in Versailles and previously, in the years preceding First World War. He steered the thoughts of national democrats concerning the Polish foreign policy, including the issue of Central Europe. According to Dmowski Poland should push for the alliance with Czechoslovakia and Romania, countries which also were concerned with protecting the Versailles order. Therefore, the main ideologist of the National Camp could not advocate the strengthening of Hungary because he deemed it to be a state possessing common goals and objectives with Germany. The following part of the text is devoted to this very issue.

\section{Hungarians as the supporters of Budapest-Vienna alliance with Berlin before the First World War}

According to Dmowski restoration of Poland was not in the interest of Hungary before the First World War. Hungarians believed that strong Germany will protect them from ambitions of national minorities in Central Europe and Balkans and therefore the alliance between Vienna and Berlin was in their best interest. For the rulers of the latter half of Habsburgs Monarchy, Hungarians, restoring the strength of Poland and the related weakening of Germany presented a great threat. Retaining Hungary in its historical borders and further rule of Magyars over Slovaks, Romanians and Serbs, nations gravitating towards the exterior and towards the centers of their national life with increasing strength, was only possible under the protection of

\footnotetext{
Ibidem.

6 Ibidem.

7 J. Snopek, Węgry. Zarys dziejów i kultury, Warszawa 2002, pp. 255-256.

8 J. Kochanowski, op. cit., pp. 67-68.

9 K. Kawalec, Roman Dmowski (1864-1939), Wrocław 1997.

10 R. Dmowski, Polityka polska i odbudowanie państwa, Warszawa 1989, vol. 1-2.
} 
strong Germany, staunchly supported by Hungarians, for whom the liberation and unification of these nations was undesirable - as Dmowski wrote in his paper ${ }^{11}$. Possible fall of Germany was to result in the disintegration of Hungary and therefore Magyars feared their territory will be reduced to the ethnographic area because they did not even constitute the majority of populace in the lands under the control of Budapest. In contrast, meeting the expectations of the aforementioned nations was in the interest of Poland. Slovaks gravitated towards Czechs, Romanians from Transylvania and Banat gravitated towards Bucharest and Serbs sympathized with the Serbian nation with the capital in Belgrade, located just beside the border between Serbia and Austria-Hungary. Dmowski also claimed that Poland posed a threat to Hungary due to its Slavic nature because Magyars, through German support, wished to rule over Slavic minorities in their territory. Therefore the alliance between Budapest-Vienna and Berlin was supposed to guarantee the rule of Germans and Hungarians over the oppressed Slavic nations. Dmowski also emphasized that the German alliance with Austria-Hungary was undeniably ruled over by Berlin: You only need to understand the political stance of Germany and you will know that they will impose it on their subordinate ally ${ }^{12}$.

Dmowski blamed both Germans and Hungarians for the participation of Habsburgs Monarchy in the war and claimed that both nations aggressively pushed for victory and were devoted to the cause ${ }^{13}$. He also underscores his disrespectful attitude towards Austria-Hungary and describes Habsburgs Monarchy as a client state of Germany ${ }^{14}$. In fact, Habsburgs could not rely on the loyalty of the significant part of their subjects who presented the attitude of indifference towards the ongoing war or visibly sympathized with the enemies of the Danube monarchy. It was apparently the most noticeable among Czechs who deserted en masse, enlisted with enemies or sabotaged state authorities from within ${ }^{15}$. Dmowski dismisses the idea of restoring independent Poland with the help of Germany and Austria advocated by the enemies of his policy ${ }^{16}$. He believed that Germany and Austria would successfully isolate Poland from the West and therefore the destruction of Habsburg Monarchy must have been a postulate of Polish policy ${ }^{17}$. He also underlined that since Austria-Hungary had entered the alliance with Germany it was gradually turned from an ally into a German protectorate. He also claimed that overthrowing Austria-Hungary monarchy as an obsolete entity unfit for the spirit of the times, aspirations and needs of the people was also an important issue ${ }^{18}$. It is prudent to note that Dmowski explained the outbreak of the Bolshevik revolution in Hungary in the following manner: revolutionary aspirations were popular only among the defeated, among Germans, Austrians, Hungarians and Bulgarians. The efforts of other nations were oriented towards comtaining the chaos and erecting foundations of their new state authority ${ }^{19}$. This was supposed to be the result of these countries blindly following Germany. Therefore

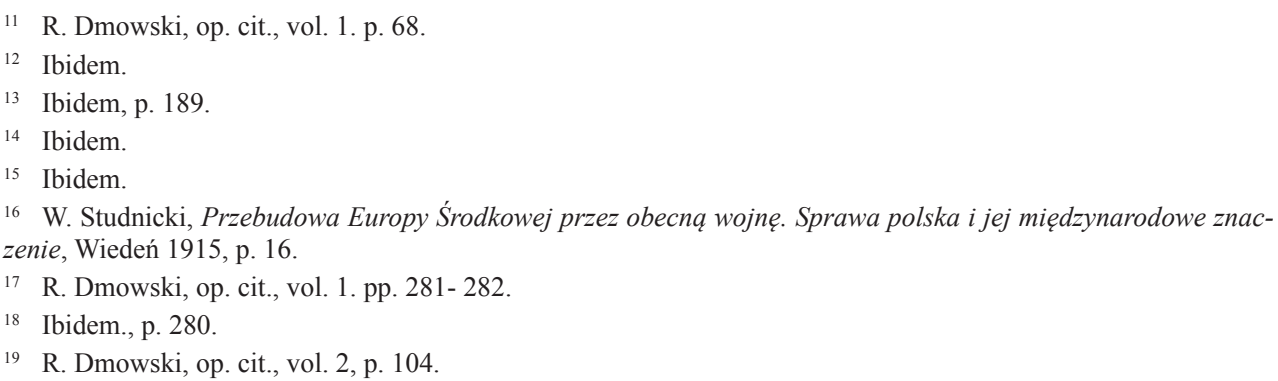


if they were engulfed in the communist revolution it meant that certain defeated nations were following the commands of socialist headquarters in Berlin ${ }^{20}$.

\section{Ethnographic Hungary in the interest of Poland?}

The members of National Democracy defended the Versailles order and so they perceived Hungary as revisionist state wishing to overthrow the new European order. This in turn, as indicated by the journalism of nationalists, was to result in Budapest gravitating towards Berlin - main enemy of the independent Poland. Therefore Hungarians were not considered to be possible allies as they had to look for support among other nations wishing to overturn Versailles provisions - Germany in particular. In the February 1920 „Gazeta Warszawska” controlled by members of National Democracy expressed support for Entente which opposed the idea of Habsburgs returning to power in Budapest ${ }^{21}$. They claimed that not long ago Habsburgs were oppressing and taming nations of Central Europe and therefore the dynasty must not take over the rule again. Simultaneously „Gazeta Warszawska” accused Magyars of strongly sympathizing with Germany. The return of Habsburgs to Budapest was supposed to reinforce German elements and incite the appetite of Germany for revising borders. The policy of Hungarian Prime Minister István Bethlen was thought of as undermining the provisions of the Treaty of Versailles ${ }^{22}$.

In his work Dmowski, however, expressed appreciation of centuries-old Polish-Hungarian friendship evidenced during, for instance, the so-called Revolution of 1848: We had a history of friendly relations with Hungarians; when they were oppressed by Austria we sympathized with them and our fathers fought in the Hungarian uprising ${ }^{23}$. However, he emphasized that when Austria-Hungary was established Magyars opted for an alliance with Berlin which was supposed to mitigate growing ambitions of independence of the minorities in Habsburgs Monarchy, Slavs in particular. This is why Hungarians pushed for close alliance between Austria-Hungary and Berlin: Hungarians were the main architects of the alliance between Habsburgs Monarchy and German Empire ${ }^{24}$. Due to this Magyars were supposed to withdraw from supporting Polish ambitions concerning independence. In a sense they had to oppose them because Polish ambitions were contrary to the basic notions of AustriaHungary foreign policy: They were making trite and shallow gestures of friendship but the policy of Hungary was, in essence, anti-Polish. Hungary provided ample evidence during the last war ${ }^{25}$. This is why Dmowski approached the issue of Hungary without emotion or sentiment - he claimed that the position of Hungary should be weakened and its territory reduced to the areas dominated by ethnically Hungarian populace. Dmowski also admitted that he wholeheartedly supports the idea of reducing Hungary to its ethnographic area ${ }^{26}$. It must be noted, however, that after the Treaty of Trianon the territory of Hungary was reduced

\footnotetext{
20 Ibidem.

21 „Gazeta Warszawska” 1920/42, p. 1.

22 Ibidem.

23 R. Dmowski, op. cit., vol. 1. p. 287.

24 Ibidem.

25 Ibidem, p. 288

26 Ibidem.
} 
even further than to the „ethnographic” area as expansive areas dominated by the Magyar population left the borders of Hungary ${ }^{27}$.

\section{Czechoslovakia and strong Romania in the interest of Poland.}

Dmowski's attitude toward Prague was different than that of many leading Polish journalists of the interwar period. Czechoslovakia was commonly accused of presenting unfavorable stance towards Poland such as during the Polish-Bolshevik war when Prague appeared to sympathize with Bolsheviks. Poles who perceived the seizure of Zaolzie region by Czechoslovakia as an insult were also numerous. Most frequently Czechs were attacked by the conservatives who consider Czechoslovakia to be an anti-clerical country under the influence of Freemasonry and artificially separating Poland from Hungary ${ }^{28}$. In contrast, the leader of National Democracy assessed the existence of Czechoslovakia as positive and in line with the interests of Poland. He marginalized the role of Slovaks claiming, not without some justification, that the state is ruled almost solely by Czechs and that is why he used terms „Czech Republic” and „Czechoslovakia”29 interchangeably. According to Dmowski: national rebirth of Czech Republic enabled us to restore Poland to our contemporary western borders $^{30}$. Furthermore, the existence of Poland was to be of particular importance for Czechs because without Poland they would become a singular Slavic island in a German sea, just like Serbs from the Łużyce region ${ }^{31}$. He noted that Prague was not inclined towards maintaining good relations with Warsaw. However, he proclaimed that even if Czechs underestimated the importance of Poland for the existence of their nation Poles should not respond with aggressive policies but should have urged toward the improvement of PolishCzech relations as they were indispensable in preventing German expansion to the East: only petty Poles who still do not understand what Poland is can push for constant squabble with $\mathrm{Czechs}^{32}$. Dmowski expressed his joy related with the establishment of Czechoslovakia and unification of Czechs and Slovaks under one nation. He even dared to proclaim that the unification of Czech Republic and Slovakia was so in line with the interests of Poland that he would have personally convinced Czechs to do so if they did not come to this conclusion themselves ${ }^{33}$. This country was to become a wall protecting Slavdom from the German expansion. According to Dmowski Czechs' effort to impose their policies on Slovaks should be supported and he considered Slovakian autonomists to be supported by Hungarians and

\footnotetext{
27 H. Batowski, Rozpad Austro-Wegier 1914-1918, Kraków 1982, pp. 286-300.

28 According to Marian Zdziechowski, a conservative journalist of „Słowo [Word]” newspaper published in Wilno by Stanisław Cat-Mackiewicz, Austria-Hungary was dissolved because they were a Catholic state and therefore hated by freemasonry lodges, ,grand capital” and Jews. In contrast he deemed Czechs to be a nation overrun by anti-clerical and lay tendencies and controlled by Freemasonry. See: M. Zdziechowski, Wegry i dookoła Wegier. Szkice polityczno-literackie, Wilno 1933, pp. 94-99; Jan Bobrzyński, another conservative journalist (related with Kraków newspaper „Czas [Time]”), wrote that the French Freemasonry and Russian Bolshevism would like to shake hands by proxy of Czech Freemasons and communists in order to isolate Poland and destroy Hungary. See: J. Bobrzyński, Naprzód Polsko!!! Wspólna granica polsko-węgierska jako nasza główna racja stanu! Odpowiedź polska na apel pięćdziesięciu wieców ludności Węgier i polski apel do Słowaków, Warszawa 1938, p. 3.

29 R. Dmowski, op. cit., vol. 1. p. 293.

30 Ibidem, p. 293.

31 Ibidem.

32 Ibidem.

33 Ibidem, p. 294.
} 
aiming for splitting Czechoslovakia: a significant part of the opposition is a Magyar opposition hidden behind Slovakian mask ${ }^{34}$. It is why he considered the attempts to establish closer relations with Budapest and the support of Hungary's ambitions concerning Slovakia to be against Polish interest ${ }^{35}$. Dmowski also presented a very positive attitude towards Romania claiming that in general there are no disputes or conflicts of interest between Warsaw and Bucharest: the issue of Romania presents no difficulties. Having taken a firm stand on the subject of the division of Hungary we supported Romania in the most important issue. If Romania had any border disputes it was not with us ${ }^{36}$. This is why he perceived Romania as a natural ally of Poland. He quoted an anecdote about a certain Romanian diplomat who was supposed to announce during the peace conference in Versailles that he will give a large award to anyone who can point out any serious dispute between Poland and Romania ${ }^{37}$. If Czechoslovakia was supposed to prevent German expansion to east, Poland and Romania were to constitute a defense against Soviets. Therefore the strengthening of Romania was supposed to be in Poland's best interest: It is in the interest of a nation for such a neighbor to be strong; he is destined to become an ally and a neighboring ally is of great political, military and economical value ${ }^{38}$. He also stated that Romania is important for the future of Poland because through this country leads the road to the Black Sea. Dmowski also added that, although he is not negatively predisposed towards Russia, in the case of Bessarabia he completely supports Romania and considers these lands to be a Romanian province ${ }^{39}$. Simultaneously he claimed that not everyone in Poland understands the role and importance of Romania because initially the Polish authority was in the hands of people who understood little about the position of Poland [...] Until this day Romanian politicians complain that we have offered them a Polish-Romanian-Hungary alliance! ${ }^{40}$

\section{Conclusion}

Dmowski passed away in the January of 1939 and soon after World War II started which turned out to be a catastrophe for arduously established Second Polish Republic. Trust in the help of England and France in case of Third Reich aggression turned out to be misplaced and speculations of conservative journalists claiming that these countries will abandon Poland turned out to be correct ${ }^{41}$. Hungary did not agree to help Germany in invading Poland but previously (March 1939) Poland briefly shared the border with Hungary after the partitioning of Czechoslovakia by Germany, Hungary and Poland ${ }^{42}$. The fall of this country has been advocated for decades by the enemies of Dmowski's policy as it was to serve interests of Poland and increase our security by way of joint border with Hungary and the fall of Czechoslovakia. Prague in the interwar period did not present favorable stance

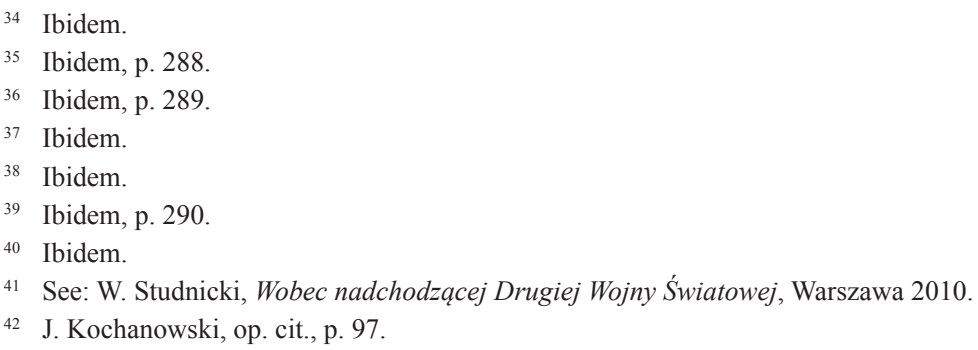


towards Poland. The disputes concerning whether Poland should join forces with Germany and move against Soviets or if the alliance with England and France was the only solution were still in progress ${ }^{43}$.

Roman Dmowski based his policy on the assumption that strong Germany is the primary threat to independent Poland. This is why he treated Hungary as a potential ally of Berlin rather than Warsaw. Centuries-old tradition of Polish-Hungarian friendship turned out to be worthless.

During the Austria-Hungary period Hungarians adapted the policy oriented towards realization of own interests and were not concerned with the fate of Poles devoid of their own, independent country. After the First World War Poland was primarily interested in upholding the Versailles order whereas Hungary was interested in toppling the current order in Central Europe. This could not result in an alliance between these two countries, especially when Warsaw still counted on more favorable policy on the part of Prague. However, instead of being an ally of Poland as expected at the time of liberation, Czechoslovakia usually engaged in rather unfavorable policy towards Poland. Maybe a possible closer relationship with Budapest would have enabled keeping Czechoslovakia in check and forced it into entering an agreement with Poland? Would such a policy have brought the intended results? We will never learn a fully satisfactory answer for these questions. However, if history is a grand teacher of life the alternative history is also not without its merits.

\section{Hungary in journalism of Roman Dmowski (based on Polish Politics and the Rebuilding of the State) Summary}

Roman Dmowski was a Polish politician and an ideological father of National Democracy. He was a very important figure for the restoration of Poland's independence after the First World War. In 1925 he published his famous book entitled "Polish Politics and the Rebuilding of the State". He explained his motives for an anti-German policy before and during the First World War. This article is focused on his relations with Hungary. Despite the tradition of Polish-Hungarian friendship, Roman Dmowski represented a rather unfriendly position towards Hungary considering policy of Budapest as favorable to Germany. Therefore, Roman Dmowski was a follower of an alliance with Prague and Bucharest instead

Keywords: Hungary, Poland, Dmowski, Foreign policy, History

About the author: mgr Michał Kowalczyk (born 1989), graduate of Institute of History, University of Warsaw, doctoral student at The Institute of Political Science of Cardinal Stefan Wyszyński University in Warsaw. Main areas of research: history and politics of Hungary, Polish-Hungarian relations, Hungarian foreign policy, nationalist movements in Central and Eastern Europe. Author of several scientific articles concerning Hungary.

\footnotetext{
43 It is worth to mention the recently popular book by Piotr Zychowicz: P. Zychowicz, Pakt Ribbentrop-Beck, Poznań 2012.
} 